\title{
Manajemen Krisis Peristiwa Tenggelamnya Kapal Di Alur Pelayaran Pelabuhan
}

\author{
Fika Suci Windriati \\ Program Studi Ilmu Komunikasi Fakultas Ilmu Sosial Ilmu Politik \\ Universitas Pembangunan Nasional "Veteran" Yogyakarta \\ Jl. Babarsari No.2 Tambakbayan Yogyakarta, Telp. 02747143421 \\ Email:wfikasuci@yahoo.com
}

\begin{abstract}
As a company in a port and harbour service business sector, the responsibility of PT. Pelindo II (Persero) of Pontianak Branch is to attempt ship flow activity, and people in the harbour is not disturbed. On February 2011, Pelindo II (Persero) of Pontianak faced an operational obstacle caused by shipwreck which is faced KLM Rahmatia Sentosa in sea voyage channel after colliding with KM Wewah. As a result, KLM Rahmatia Sentosa is sink and it is difficult to be evacuated so that it interferes sea voyage traffic current to Pontianak. The incident widely impacted to West Kalimantan's economcis as a whole and demand the harbour management company party to immediately handle the problem caused by the crisis situation. This research utilizes a descriptive qualitative method with observation, interview, and library study data collecting techniques. It is aimed to find out the crisis management strategic and role of public relation of PT. Pelindo II of Pontianak in he crisis of the sinking ship in harbour sea voyage channel and to compare with the utilized theory. The utilized theories in this research are public relation, crisis, and crisis management theories. The crisis have to be managed quickly, appropriately, and accurately, which is with a crisis management. The shipwreck and the difficult evacuation is an example of crisis faced by PT. Pelabuhan Indonesia II (Persero) of Pontianak Branch in 2011. In the incident, Pelindo II (Persero) of Pontianak handled the crisis with an adaptive strategic with the steps of image handle of a crisis communication. The inexistence of crisis management team particulary makes Pelindo to prepare a general plan in the management to react toward crisis. The role of public relation in Pelindo crisis is done by General Manager because the existence role of public relation is less in Pelindo Management because Pelindo's orientation is to business and it makes public relation only as a management back up in marketing sector. Key words: Analysis; Crisis Management Strategic; Role of Public Relations
\end{abstract}

\begin{abstract}
Abstrak
Sebagai perusahaan di sektor bisnis jasa pelabuhan, PT. Pelindo II (Persero) Cabang Pontianak adalah untuk mencoba aktivitas arus kapal, dan orang-orang di pelabuhan tidak terganggu.Februari 2011, Pelindo II (Persero) Pontianak menghadapi kendala operasional akibat kapal karam yang dihadapi KLM Rahmatia Sentosa di jalur pelayaran laut setelah bertabrakan dengan KM Wewah. Akibatnya, KLM Rahmatia Sentosa tenggelam dan sulit dievakuasi sehingga mengganggu arus lalu lintas pelayaran laut ke Pontianak. Kejadian tersebut berdampak luas pada ekonomi Kalimantan Barat secara keseluruhan dan menuntut pihak perusahaan pengelola pelabuhan untuk segera menangani masalah yang disebabkan oleh situasi krisis. Penelitian ini menggunakan metode kualitatif deskriptif dengan teknik pengumpulan data studi observasi, wawancara, dan perpustakaan. Tujuannya untuk mengetahui strategi manajemen krisis dan peran humas PT. Pelindo II Pontianak dalam krisis tenggelamnya kapal di jalur pelayaran laut pelabuhan dan untuk dibandingkan dengan teori yang digunakan. Teori dalam penelitian ini adalah hubungan masyarakat, krisis, dan teori manajemen krisis. Krisis harus dikelola dengan cepat, tepat, dan akurat, dengan manajemen krisis. Kapal karam dan evakuasi yang sulit adalah contoh krisis yang dihadapi oleh PT. Pelabuhan Indonesia II (Persero) Cabang Pontianak pada tahun 2011. Dalam insiden tersebut, Pelindo II (Persero) Pontianak menangani krisis dengan strategi adaptif dengan langkah-langkah penanganan citra komunikasi krisis. Tidak adanya tim manajemen krisis secara khusus membuat Pelindo menyiapkan rencana umum dalam manajemen untuk bereaksi terhadap krisis. Peran public relation dalam krisis Pelindo dilakukan oleh General Manager karena peran public relation kurang dalam Manajemen Pelindo karena orientasi Pelindo adalah untuk bisnis dan itu membuat public relations hanya sebagai back up manajemen di sektor pemasaran. Kata kunci: Analisis; Strategi Manajemen Krisis; Peran Hubungan Masyarakat
\end{abstract}




\section{Pendahuluan}

Indonesia merupakan negara kepulauan yang dua pertiga wilayahnya adalah perairan dan terletak pada lokasi yang strategis karena berada di persilangan rute perdagangan dunia. Sehingga peran pelabuhan dalam mendukung pertumbuhan ekonomi maupun mobilitas sosial dan perdagangan di wilayah ini sangat besar. Oleh karenanya pelabuhan menjadi faktor penting bagi pemerintah dalam menjalankan roda perekonomian negara. Peran dan fungsi pelabuhan menjadi sangat penting, pelabuhan merupakan sebagai pintu gerbang ekonomi dan penggerak kegiatanperdagangan dalamrangkameningkatkan dan mempercepat aktivitas ekonomi regional.

Untuk wilayah Kalimantan Barat PT. Pelindo II (Persero) mengelola pelabuhan Dwikora Pontianak yang terletak ditepi sungai Kapuas, menjadi urat nadi perekonomian dan menghubungkan area seluas 146,8 ribu km2 di Provinsi Kalimantan Barat. Hinterlan pelabuhan ini didominasi oleh perkebunan, kehutanan, sektor pertambangan serta industri pengolahan bahan mentah.

Pada bulan Febuari 2011 PT Pelindo II (Persero) khususnya daerah cabang pelabuhan Pontianak mengalami hambatan dalam kegiatan operasional perusahaan. Hal ini disebabkan oleh kecelakaan laut yang dialami KLM Rahmatia Sentosa di alur pelayaran setelah bertabrakan dengan KM Wewah. Akibatnya kapal Rahmatia Sentosa tenggelam dan kegiatan lalu lintas melalui jalur pelayaran Pontianak saat itu lumpuh total. Satu-satunya akses ke pelabuhan Dwikora Pontianak adalah melalui muara sungai karena letak pelabuhan tersebut ada di tepi sungai Kapuas. Badan kapal yang tenggelam menutupi jalur pelayaran, sehingga kapal-kapal yang keluar masuk pelabuhan tidak bisa berlayar.

Hingga bulan Maret 2011, kapal yang tenggelam tersebut masih sulit dievakuasi, itu disebabkan oleh muatan kapal yang membawa 14 ribu sak semen, karena tenggelam dan bercampur air maka semen-semen tersebut membatu. Gagalnya proses evakuasi karena medan yang cukup berat, seperti arus deras, badan kapal itu yang telah tertutup lumpur setinggi tiga meter dan semen yang telah menyatu sehingga sulit diangkat. Para penyelam tradisional dikerahkan untuk mengangkat ribuan sak semen tersebut, sampai akhirnya badan kapal bisa diapungkan menggunakan alat dengan sistem balon setelah muatan kapal lebih ringan dari sebelumnya. Proses evakuasi ini memakan waktu yang cukup lama.

Akibat dari peristiwa ini menciptakan situasi yang sangat berpengaruh pada seluruh masyarakat wilayah Kalimantan Barat, yakni kesulitan mendapatkan bahan bakar minyak. Pasokan BBM terhambat di pelabuhan Pontianak, dan Pertamina berupaya mendistribusikan BBM dengan pengiriman dari kapal ke kapal sehingga perlu upaya kendali suplai. Terjadi antrian panjang masyarakat pada setiap stasiun pengisian bahan bakar umum (SPBU) di Pontianak dan daerah kabupaten sekitarnya. Kelangkaan ini menyebabkan harga melambung tinggi di kioskios penjualan BBM. Masalah yang menyangkut BBM sangat sensitif bagi masyarakat luas, karena BBM adalah kebutuhan dasar bagi kehidupan sehari-hari. Selain fenomena tersebut, masalah badan kapal yang masih sulit untuk dievakuasi masih menjadi kendala bagi kelancaran alur pelayaran pelabuhan Dwikora Pontianak. Tentu saja hal ini menyebabkan penumpukan barang dan antrian panjang kapal-kapal yang hendak masuk ke wilayah Pontianak, kerugian para pengusaha pun tak terhindarkan akibat kondisi ini. Pihak yang mengatasi masalah ini secara langsung dilapangan adalah Administrator Pelabuhan (Adpel) dan Pelindo. Situasi ini memicu pula ikut serta pemerintah dalam mengintervensi perusahaan pengelola pelabuhan untuk mengendalikan dan mengatasi masalah ini secepatnya. Media massa lebih cepat dan terus menerus memberitakan karena dampak kejadian ini meluas pada seluruh wilayah suatu daerah. 
Situasi ini dapat dikatakan krisis, terutama adalah krisis bagi perusahaan yang bertanggungjawab menangani situasi ini secara langsung dilapangan. Hampir semua perusahaan pernahmengalamikrisis. Suatukrisis didefinisikan oleh berbagai aspek dari suatu situasi, yang mencakup suatu ancaman yang tinggi terhadap kehidupan keamanan atau eksistensi suatu organisasi dan tekanan waktu, yang berarti para pengambil keputusan harus bekerja dengan cepat untuk menanggulangi situasi (Afdhal, 2004: 111).

Organisasi atau perusahaan tidak ada yang ingin mengalami krisis. Hal ini terkadang membuat mereka lupa bahwa krisis tetap dapat terjadi dan tidak dapat terhindarkan di perusahaan mereka. Sehingga banyak pengelola perusahaan yang tidak sadar bahwa rencana khusus dalam penanganan krisis yang dapat muncul adalah penting (Luhukay, 2008).

Krisis menciptakan perusahaan dalam posisi menjadi perhatian masyarakat sehingga mempertanyakan kompetensi manajemen perusahaan. Oleh karena itu perusahaan harus berkomunikasi dengan cepat, akurat dan terampil dengan beberapa kelompok penting seperti karyawan, media, pemegang saham, stakeholder, bahkan pemerintah. Pada saat yang sama, tercipta kondisi yang akan menyulitkan para eksekutif untuk membuat keputusan yang baik dan berkomunikasi dengan tepat. Dalam hal ini, praktisi public relations dapat bertindak sebagai komunikator atau mediator yang membantu pihak manajemen mendengar apa yang diinginkan dan diharapkan oleh publiknya. Di pihak lain, praktisi public relations juga dituntut mampu menjelaskan kembali keinginan, kebijakan, dan harapan organisasi kepada publiknya. Diharapkan dengan komunikasi timbal balik ini dapat tercipta saling pengertian, saling percaya, saling menghargai, saling mendukung, dan toleransi yang baik dari kedua belah pihak. Peran public relations dalam suatu organisasi salah satunya ialah menjadi fasilitator proses pemecahan masalah (problem solving process fasilitator) yang merupakan bagian dari tim manajemen. Hal ini dimaksudkan untuk membantu pimpinan perusahaan baik sebagai penasihat hingga mengambil tindakan eksekusi dan keputusan dalam mengatasi persoalan atau krisis yang tengah dihadapi secara rasional dan profesional. Public Relations juga harus memiliki keterampilan sehingga memberikan sumbangan dalam menanggulangi manajemen krisis. Public Relations dituntut untuk tidak sekedar menanggulangi krisis, tetapi membangun perusahaan beserta reputasinya kembali setelah krisis berakhir. Disini dibutuhkan suatu perencanaan yang matang dengan dasar informasi yang akurat, sejauh mana kerusakan yang ditimbulkan oleh krisis tersebut. Diperlukan pula perencanaan jangka panjang dan kemampuan mengukur kemajuan yang diperoleh dalam merestorasikan perusahaan.

Pengertian Public Relations sendiri adalah fungsi manajemen dari hal yang saling berkaitan dan berencana. Organisasi dan lembaga yang bersifat umum dan pribadi berusaha untuk memperoleh pengertian, simpati, dan dukungan dari pihak lain yang terlibat atau bertujuan sebisa mungkin menghubungkan kebijaksanaan dan ketatalaksanaan mereka untuk mencapai kerja samayanglebih produktifdanuntukmelaksanakan kepentingan bersama yang lebih efisien, dengan melancarkan informasi yang berencana dan tersebarluas(Kurniasari, Lestari, \& Isbandi, 2008).

\section{Metode Penelitian}

Penelitian ini diklasifikasikan ke dalam penelitian kualitatifdeskriptifyang berusahauntuk mengembangkan konsep-konsep. Bertujuan mengetahui konsep manajemen krisis yang digunakan oleh PT Pelindo II (Persero) Cabang Pontianak dalam kasus tenggelamnya kapal di alur pelayaran pelabuhan dan membandingkannya dengan teori yang digunakan. Penelitian dengan pendekatan deksriptif adalah penelitian yang menggambarkan secara lebih kelas situasi sosial atau eksplorasi dan klarifikasi tentang suatu fenomena atau kenyataan sosial (Mulyadi, 2011). 
Sumber data yang digunakan dalam penelitian ini berupa data primer yaitu data yang diperoleh langsung dari informan di PT Pelindo II (Persero) Pontianak dan data sekunder yaitu data yang diperoleh dengan mengutip dari sumber lain yang bertujuan untuk melengkapi data primer, seperti: literatur, dokumentasi perusahaan, kliping pemberitaan pada media massa, dan wawancara dengan responden yang memiliki informasi tambahan.

Teknik pengumulan data dengan observasi yakni peneliti melakukan pengamatan langsung pada objek penelitian, selain mengenai kinerja manajemen PT. Pelindo II (Persero) Pontianak, peneliti mengamati secara langsung aktivitasaktivitas yang ada di pelabuhan Dwikora Pontianak dan mencoba memahami, mencari tahu keterkaitan dan dampak-dampak situasi krisis pada masyarakat secara luas. Ini perlu dilakukan karena dari sini dapat diketahui data secara akurat, bagaimana pihak manajemen Pelindo berusaha untuk keluar dari masalah yang dialami perusahaannya. Melalui wawancara peneliti melakukan percakapan dengan sumber yang berhubungan langsung pada kejadian yang sedang diamati untuk mendapatkan informasi yang lebih objektif dan sesuai dengan pendekatan yang digunakan oleh peneliti. Studi pustaka juga dilakukan untuk mengumpulkan data-data, peneliti memanfaatkan berbagai macam data dan teori yang dikumpulkan melalui buku-buku, internet, majalah, surat kabar, makalah, seminar dan informasi sebagai penunjang penelitian serta bahanbahan tertulis lainnya sebagai dasar penulisan.

Untuk dapat menganalisis data, peneliti terlebih dahuluharus melakukan penelitiandengan jalan mengumpulkan sebanyak-banyaknya data yang berhubungan dengan penelitian (data collection). Pengumpulan data dilakukan melalui studi pustaka dan wawancara dengan informan yang sesuai dengan penelitian. Setelah data terkumpul, data diseleksi (data reduction), agar dapat ditarik suatu kesimpulan (conclusions), sehingga data dapat ditampilkan (data display).
Dalam konteks penelitian ini, uji validitas data yang digunakan adalah triangulasi sumber data dimana peneliti meminta pertimbangan pihak lain atas isu yang sedang diteliti. Tiga sumber metode triangulasinya adalah PT Pelindo II (Persero) Pontianak, Media Massa, danPengguna Jasa Pelabuhan. Dari ketiga sumber diatas maka didapatkan data yang dapat di pertanggungjawabkan objektifitasnya dan keabsahannya karena tidak berasal dari satu sumber saja melainkan dengan mengolah berbagai data yang ada dari sumber yang berbeda.

\section{Hasil Penelitian Dan Pembahasan \\ Strategi Manajemen Krisis Pelindo Pontianak}

PT. Pelindo II (Persero) Pontianak tidak memiliki manajemen krisis secara khusus, akan tetapi ketika menghadapi persoalan tenggelamnya kapal di alur pelayaran pelabuhan pada bulan Febuari 2011, Pelindo menyadari bahwa untuk mengatasi krisis manajemen perlu melakukan tindakan, strategi penanganan masalah di lapangan, dan strategi untuk menghadapi pertanyaan publik termasuk pemerintah dan media untuk meminimalkan dampak krisis. Semua itu sudah termasuk didalam strategi manajemen krisis Pelindo.

$$
\text { Upaya Pencegahan Krisis Dengan }
$$

Manajemen Resiko: Pelindo menyadari kemungkinan menghadapi kejadian yang tidak terduga sebelumnya karena setiap perusahaan bisa menghadapi masa depan yang bisa berubah arah dan tidak bisa diduga (uncertainty condition). Untuk itu peramalan akan resiko kejadian tidak terduga atau yang dapat berkembang menjadi krisis perlu dilakukan pada situasi pra-krisis. Kemungkinan krisis dalam kegiatan organisasi dapat dilakukan identifikasi melalui manajemen resiko sehingga dapat dikenali resiko yang berpotensial menjadi masalah dalam krisis. Dalam manajemen Pelindo terdapat manajemen resiko yang dibawahi langsung oleh Assisten General Manager. Ini mengidentifikasikan bahwa manajemen Pelindo memandang penting dalam mengelola faktor resiko agar kelangsungan perusahaan dapat diperkirakan. 
Manajemen krisis bertujuan untuk menekan faktor-faktor resiko dan faktor ketidakpastian seminimal mungkin. Pelindo menghadapi uncertainly condition atau kondisi yang tidak diduga sebelumnya karena tipe krisis yang muncul adalah sudden crises (tibatiba) atau yang bersifat segera (immediate crises) yang disebabkan human error dan kecelakaan kapal yang menyebabkan gangguan layanan hingga permasalahan evakuasi yang mengganggu operasional bisnis secara normal.

Manajemen krisis memang berbeda dengan manajemen resiko. Akan tetapi jika mengelola resiko dengan baik, hal-hal yang berpotensi menjadi krisis dapat direspon dengan perencanaan yang baik. Manajemen resiko adalah proses pengukuran atau penilaian resiko serta pengembangan strategi pengelolaannya. Strategi yangdapatdiambilantaralainadalahmemindahkan resiko kepada pihak lain, menghindari resiko, mengurangi efek negatif resiko, dan menampung sebagian atau semua konsekuensi resiko tertentu.

Manajemen dapat menanggulangi krisis dengan melakukan peramalan krisis (forcasting), manajemen krisis bertujuan untuk menekan faktor-faktor resiko dan faktor ketidakpastian seminimal mungkin. Setiap perusahaan menghadapi masa depan yang selalu berubah dan arah perubahannya tidak bisa diduga. Esensi manajemen krisis adalah upaya untuk menekan faktor ketidakpastian dan faktor resiko hingga tingkat yang paling rendah. Manajemen krisis diawali dengan mengumpulkan informasi sebanyak mungkin mengenai faktor-faktor yang berpotensi mengakibatkan krisis pada perusahaan. Jika hal tersebut diketahui maka pengambilan keputusan mengenai langkah-langkah yang harus diambil dapat disiapkan sebelum krisis terjadi.

Langkah-langkah pencegahan sebaiknya diterapkan pada situasi pra krisis, untuk mencegah kemungkinan terjadinya krisis dan manajemen dapat mengupayakan agar krisis tidak menimbulkan kerugian yang besar. Terkait dengan kecelakaan di alur Mura Jungkat, manajemen
Pelindo sudah memiliki monitoring resiko dalam sistem manajemen keselamatan kerja. Objek aktivitas bagi Pelindo disini adalah dalam jalur bisnis pemanduan, dalam kegiatan penanganan sudah berusaha menghindari kecelakaan dengan menempatkan operator pada stasiun pandu yang berfungsi mengawasi dan menjaga komunikasi jarak laut. Meskipun potensi kecelakaan berusaha untuk dihindari namun tetap saja bisa terjadi karena human error atau ketidaktertiban pengguna alur lalu lintas pelayaran. Langkah pencegahan krisis ini dilakukan Pelindo karena manajemen Pelindo tidak ingin mengabaikan peluang untuk mengidentifikasikan potensi resiko. Ini perlu dilakukan manajemen untuk memastikan apakah perusahaan berjalan dengan baik atau sebaliknya.

\section{Upaya Penanggulangan Krisis}

Salah satu karakter krisis adalah adanya keterkejutan. Tekanan yang kuat saat penyelesaian krisis adalah bagian dari manajemen krisis. Untuk menyelesaikan krisis tersebut, manajemen Pelindo merespon dengan melakukan intervensi krisis. Langkah intervensi dalam situasi krisis bertujuan untuk mengakhiri krisis. Pelindo merasa harus turun tangan mengelola krisis karena kejadian ini sangat berpotensi mengganggu jalannya kegiatan operasional perusahaan. Pelindo menentukan langkah-langkah pengelolaan krisis sebagai berikut: Identifikasi Krisis, Identifikasi terhadap krisis perlu dilakukan untuk melakukan perencanaan atau implementasi tindakan tepat yang perlu dilakukan oleh manajemen. Pihak manajemen berusaha menganalisis situasi, berusaha untuk mampu memprediksikan kemungkinan buruk yang akan terjadi selanjutnya, dan merumuskan metode pemecahan masalah atau solusi yang efektif dan efisien. Krisis terjadi karena permasalahan setelah kecelakaan tabrakan kapal yang menyebabkan salah satu kapal tenggelam dan sulit dievakuasi karena kondisi kapal dan alam serta terbatasnya tenaga ahli, alat, dan biaya yang dimiliki membuat usaha Pelindo untuk menyelesaikan krisis dengan cepat menjadi tersendat. 
Pilihan Strategi: pilihan strategi adalah upaya yang dilakukan Pelindo untuk mengelola krisis akibat kecelakaan kapal di alur pelayaran pelabuhan. Akibat kejadian tersebut terjadi perubahan dalam lingkungan bisnis Pelindo yang menyebabkan kelangsungan operasional perusahaan menjadi terganggu. Sehingga Pelindo memiliki rencana dalam penetapan strategi menghadapi krisis untuk menghindari keputusan yang justru akan membuat perusahaan terperosok lebih jauh dalam krisis. Pelindo melakukan penetapan strategigenerikyakniAdaptive Strategi, langkah-langkah yang diambil mencakup hal-hal yang lebih luas, seperti: Modifikasi operasional (Pelindo mengupayakan aktivitas bongkar muat kapal tetap berjalan meski dilakukan ditengah muara, dengan proses pemindahan dari kapal ke kapal agar arus barang ke pelabuhan tidak tersendat. Meminta Kepolisian Air Pontianak untuk menjaga dan mengamankan aktivitas bongkar muat tersbut agar tidak ada oknum yang memanfaatkan situasi ini. Mengoperasikan kapalkapal pemandu agar dapat mengelola kapal-kapal yang tetap bisa masuk, kapal dengan kedalaman lambung (draf maksimal) 4 meter dilayani untuk melewati alur yang terhalang KLM Rahmatia Sentosa yang karam sehingga bahan bakar minyak dan sembako bisa masuk. Menyediakan tongkang yang dipergunakan untuk bongkar muat barang hingga berat kapal yang akan masuk ke pelabuhan tidak lebih draf 4 meter.

Kompromi (Manajemen Pelindo tidak hanya melibatkan internal perusahaan tetapi juga pihak lain yang berkaitan dan bisa memberikan peran yang membantu untuk menyelesaikan krisis. Pihak-pihak yang terlibat ini bisa dimanfaatkan kapasitasnya untuk menghasilkan expertise judgement, opinion leader statement, ataupun juru runding permasalahan yang ada dan sudah menyangkut kepentingan banyak pihak. Pihak yang dipilih adalah pihak instansi yang memiliki kapabilitas dan dapat dipercaya baik oleh manajemen Pelindo ataupun publik atau masyarakat luas. Keterlibatan pihak-pihak tersebut antara lain dalam bentuk kegiatan.
Meluruskan citra (Manajemen Pelindo merasa perlu memastikan bagaimana citra perusahaan diposisikan di hadapan publik berkaitan dengan peristiwa yang mengakibatkan hambatan operasional di pelabuhan. Maka untuk mendapatkan citra yang baik manajemen memberi informasi mengenai realitas yang terjadi. Dengan adanya insiden tabrakan kapal dan lamanya proses evakuasi kapal tersebut, terbentuk opini di masyarakat kalau Pelindo tidak professional dan kurang baik dalam aktivitas pelayanan pemanduan kapal. Untuk menanggapi hal tersebut jumpa pers dilakukan beberapa kali dihadapan media bersama Adpel bertujuan memberikan informasi penyebab kecelakaan dan penanganan yang akan diambil serta upaya yang telah dilakukan Pelindo agar arus barang tidak terganggu. Menginformasikan kendala yang dihadapi Adpel sehingga proses evakuasi berjalan lama, salah satunya kondisi di lapangan, kurangnya biaya, dan tidak adanya tenaga ahli yang dapat menangani proses evakuasi).

Komunikasi Krisis: komunikasi krisis adalah komunikasi antara organisasi dengan publik sebelum, selama, dan setelah kejadian krisis. Komunikasi ini dirancang melalui programprogram untuk meminimalisir kerusakan terhadap citra perusahaan. Strategi komunikasi yang dijalankan oleh Pelindo II Pontianak melalui General Manager yaitu Ingratiation Strategies (Combs 1994) dimana Pelindo berupaya mencari dukungan publik dengan membentuk pesan berupa pengingatan akan hal-hal yang sudah diupayakan Pelindo untuk membantu mengatasi permasalahan evakuasi kapal di alur pelayaran pelabuhan. Terlihat dari beberapa media yang rutin menginformasikan upaya evakuasi lanjutan dan upaya Pelindo dalam melayani dan menjamin kelancaran barang dan orang dengan mengelola kapal-kapal yang dimungkinkan untuk tetap bisa masuk ke Pelabuhan. Untuk mempertimbangkan publik organisasi, Pelindo mengambil upaya komunikasi krisis dengan Konferensi Pers. Strategi ini untuk menanggapi 
pihak media dan membantu publik mengetahui lebih jauh keadaan yang terjadi sebenarnya, Tim penanganan evakuasi kecelakaan yang terdiri dari pihak Adpel dan Pelindo beberapa kali menggelar konferensi pers dengan materi perkembangan terakhir evakuasi. General Manager hadir mewakili manajemen Pelindo mendampingi kepala Adpel beserta Manager Operasional yang bertindak sebagai pembicara. Fungsinya pada acara itu sebagai pengontrol arus informasi agar tidak terjadi kesimpangsiuran yang membingungkan wartawan.

\section{Peran Public Relations dalam Manajemen} Krisis Pelindo Pada Masa Krisis

Adapun peranan public relations dalam manajemen Pelindo terlihat pada aktivitas pokok yaitu melaksanakan penggiat aktivitas public relations sebagai Back Up Manajemen. Dalam struktur organisasi manajemen Pelindo, Humas dan Pemasaran menjadi satu kesatuan, dibawahi langsung oleh Manager Pemasaran dan Pelayanan Pelanggan serta Assisten General Manager sebagai Pengendalian Kinerja \& PPSO. Melihat posisi Humas di Pelindo dapat diidentifikasikan aktivitas Humas lebih banyak berkaitan dengan pemasaran dan pelayanan pelanggan dalam aktivitas bisnis perusahaan. Sedangkan peran serta Humas Pelindo dalam situasi krisis ialah sebatas komunikasi internal untuk memberikan informasi dan fakta terbaru dilapangan kepada pihak manajemen.

Ada dua hal yang menyebabkan hambatan kinerja pada public relations Pelindo sehingga peran daripublic relations sendirisangatsedikitdan terbatas, yakni yang pertama karena perusahaan masih belum menganggap penting fungsi public relations dalam manajemen, dan yang kedua praktisi public relations Pelindo sendiri tidak dapat menunjukan peran yang maksimal sebagai public relations. Pelindo termasuk perusahaan yang tidak memanfaatkan public relations secara efektif, karena posisi serta fungsi dan peran public relations dalam manajemen Pelindo adalah dibawah Divisi Pemasaran dan Pelayanan Pelanggan. Penempatan public relations dalam posisi ini tentu saja kurang atau tidak punya akses langsung pada pimpinan perusahaan. Persoalan yang lain dalam manajemen adalah kekurangsadaran bahwa masalah citra bukanlah tanggung jawab public relations semata, melainkan tanggung jawab semua individu anggota perusahaan. Selain itu public relations Pelindo secara pribadi tidak pula memiliki kecakapan dalam menggerakkan aktivitas dan peran public relations secara maksimal. Hal tersebut tercermin pada ketiadaan program perencanaan public relations (PR Planning) atau perencanaan krisis (Crisis Planning).

Public Relations bisa menjadi pilihan bagi organisasi ketika krisis terjadi, ketika datang masalah seperti media yang memblow up berita Pelindo di koran lokal maupun nasional tentang krisis BBM di wilayah Kalbar yang dikaitkan dengan proses evakuasi kapal yang tidak segera selesai. Public Relations seharusnya hadir dalam organisasi bukan menjadi suatu kebetulan, tetapi hadir sebagai suatu kebutuhan, Public Relations adalah suatu proses yang dilakukan dengan perencanaan. Public Relations hadir sebagai suatu kebutuhan, kebutuhan untuk menjembatani organisasi dengan para pemangku kepentingan (stakeholders). Jembatan yang dibangun public relations berdiri atas dasar Trust, Honest dan Credibility. Public Relations ada, karena ada kepercayaan. Artinya masyarakat percaya pada organisasi dan organisasi percaya pada masyarakat atas dasar saling pengertian dan winwin solution. Public Relations membangun citra dan reputasi organisasi lewat opini public yang menguntungkan (favourable) melalui kaca mata publik yang memotret aktivitas organisasi di media massa. Lewat citra dan reputasi, organisasi tetap dapat berdiri kokoh dalam ranah kompetisi merebut pangsa pasar dan servis dari organisasi. 
Dengan adanya situasi krisis, perusahaan tidak bisa menghindari tekanan dari media. Pemberitaan yang menyudutkan dan berbagai opini serta asumsi yang tersiar di media massa tidak mudah dielakkan, apalagi kejadian ini telah mempengaruhi berbagai aspek masyarakat terutama ekonomi bagi wilayah Kalbar. Melihat hal ini, peran kehumasan sangatlah penting dalam mengarahkan informasi menuju pengertian dan dukungan publik kepada perusahaan. Hubungan antara public relations dengan media adalah sebuah hal yang tidak dapat dipisahkan, pada satu sisi media dapat menjadi alat bantu yang menunjang berhasil tidaknya strategi public relations sebuah perusahaan dijalankan namun dilain sisi media juga dapat menjadi boomerang bagi perusahaan dan akan mempengaruhi tingkat keberhasilan yang dicapai dari strategi public relations yang dijalankan.

General Manager Pelindo Sebagai Penggerak Aktivitas Public Relations di Masa Krisis

Saat krisis berlangsung, aktivitas public relations oleh manajemen Pelindo lebih banyak dilakukan oleh General Manager selaku pimpinan tertinggi di perusahaan, dengan melihat pertimbangan pimpinan tertinggi Pelindo Bapak Solikhin selaku General Manager langsung turun tangan pada tahap awal hingga akhir proses penyelesaian masalah, baik secara internal maupun eksternal perusahaan. Perhatian dan keseriusan General Manager menangani evakuasi kecelakaan adalah unsur strategis krisis kehumasan. Sedangkan untuk internal sendiri, General Manager meminta bagian pegawai manajemen Pelindo mendapat bagian piket khusus/jadwal penjagaan untuk memantau dan mengawasi proses evakuasi di tempat kejadian, agar informasi dan keadaan terbaru didapat manajemen sebagai pertimbangan untuk memikirkan langkah selanjutnya. Untuk meluruskan pemberitaan pers, manajemen mengundang wartawan, memfasilitasi mereka yang ingin ikut serta dalam perjalanan para manager dan pimpinan yang tengah sibuk mengurus dan memantau proses evakuasi, dengan menyediakan boat khusus menuju lokasi kejadian. Kegiatan itu akan menimbulkan kesan bahwa pimpinan perusahaan tidak memikirkan hal-hal lain, kecuali mencurahkan perhatian dan energinya untuk mengurusi hal tersebut. Dengan membawa media melihat langsung dan dekat dengan lokasi kejadian Pelindo merasa tidak perlu banyak bicara, apalagi mengatur gerak-gerik dan apa yang hendak dilaporkan wartawan. Membiarkan wartawan dengan bebas melihat hal-hal yang nyata dengan mata mereka. Kebebasan mengobservasi dan mendapatkan informasi merupakan nilai lebih yang efektif untuk merebut sikap pemihakan wartawan.

Selain membebaskan wartawan bekerja, selaku General Manager Pelindo merasa harus dengan tangkas mengumpulkan semua informasi yang berkaitan dengan perkembangan evakuasi dan situasi-situasi krisis yang menyertainya guna melayani kebutuhan wartawan akan informasi terbaru. Beberapa pemberitaan media tentang akibat terjadinya kecelakaan di alur Muara Jungkat mengindikasikan kurangnya pengawasan dalam kegiatan operasional Pelindo dan kondisi alur yang terlalu sempit untuk lalu lintas kapal sehingga membutuhkan perhatian untuk melakukan tindakan pembukaan alur baru. Selain itu kurang tanggap atas keadaan darurat mengatasi kecelakaan dan lambannya proses evakuasi menjadi agenda berita yang terus menyudutkan Pelindo. Untuk meluruskan pemberitaan tersebut pihak perusahaan melakukan beberapa strategi penyebaran informasi yang dijalankan langsung oleh General Manager sebagai spoke person yakni: Mengklarifikasi bahwa pihak yang berwewenang penuh dan memiliki otoritas alur adalah Adpel, sedangkan Pelindo sebagai pelaksana teknis pelayanan jasa. Jadi dalam upaya evakuasi lapangan Pelindo sebagai partisipan. Ikut serta memberi informasi mengenai hambatan evakuasi dan mempublikasikan hasil setiap rapat koordinasi dengan pihak-pihak terkait dan 
upaya yang akan dilakukan selanjutnya dalam evakuasi kapal tenggelam yang menghambat alur pelayaran melalui konferensi pers. Membuka akses langsung kepada media untuk mendapatkan informasi yang objektif tentang upaya evakuasi yang tengah dilakukan, serta upaya Pelindo dalam membuka akses pelayanan kapal yang masih bisa masuk pelabuhan, dan pimpinan General Manager sebagai spoke person. Melakukan tindakan langsung sebagai salah satu bentuk aksi "emergency planning" dan sebagai bentuk tanggungjawab perusahaan terhadap pengatur pemanduan kapal di alur dan aktivitas pelabuhan. Pelindo berusaha agar kegiatan pelabuhan tetap berjalan dengan mengupayakan kapal-kapal dengan draft tidak lebih dari 4 meter untuk dipandu masuk ke pelabuhan agar arus kapal dan barang tidak terganggu pelaksanaannya.

Sebuah strategi public relations yang dijalankan oleh perusahaan dalam menghadapi tekanan media yang terkadang menyudutkan perusahaan adalah dengan membuat jalur informasi menjadi satu jalur saja. Pelindo menerapkan "one gate keeper" bagaimana perusahaan menginformasikan berbagai berita yang datang dari perkembangan proses evakuasi, disini Pelindo menjaga segala bentuk manipulasi berita yang digunakan untuk menciptakan asumsi bahwa perusahaan ikut berpartisipasi penuh dalam penyelesaian kasus tersebut. Perusahaan menjaga objektifitas berbagai informasi yang dibutuhkan oleh media dengan maksud agar berita yang dibuat media memang berdasarkan pada bukti yang kuat dan benar adanya sehingga tidak muncul penyimpangan informasi dalam media, General Manager Pelindo menjalankan peran public relations sebagai satu-satuya sumber informasi dimana wartawan mendapatkan berbagai informasi yang berasal dari tim evakuasi dan apa yang telah diupayakan Pelindo.

Pengambil-alihan peran public relations oleh general manager Pelindo pada saat krisis dikarenakanPelindotidakmempersiapkan praktisi public relations untuk menghadapi kejadian besar yang tidak terduga atau sebagai problem solving di dalam manajemen perusahaan. Aktivitas public relations di saat krisis bisa dilakukan oleh siapa saja yang bisa diandalkan dan memiliki kredibilitas di dalam manajemen perusahaan sesuai dengan keputusan top management. Ketika perusahaan sedang mengalami kejadian besar yang berdampak merugikan atau disebut dengan situasi krisis maka perlu adanya keputusan yang tepat untuk memilih strategi atau program penanggulangan krisis. Keputusan tersebut bukanlah keputusan yang mengandalkan intuisi belaka melainkan berdasar pada keputusan top manajemen dengan dasar pertimbangan dari Public Relations, dimana posisi Public Relations seharusnya berdekatan atau memiliki akses langsung dengan top manajemen. Dalam situasi krisis Pelindo keputusan diatas bisa diambil dengan singkat karena pimpinan tertinggi juga mengemban tugas sebagai public relations. Sehingga ketika seharusnya public relations bisa membantu meringankan kesulitan yang dialami pimpinan, hal tersebut tidak terdapat pada public relations di dalam manajemen krisis Pelindo. Public Relations seharusnya bisa berperan sebagai mata, telinga dan corong dari perusahaan, tidak bergerak sendiri melainkan bergerak bersama seluruh komponen organisasi tersebut, terlebih jika krisis tengah melanda perusahaan. Karena itu peran public relations yang dewasa ini lebih ditekankan pada membantu pemecahan masalah di perusahaan bisa menjadi suatu keharusan. Manajemen Krisis (Crisis Management) merupakan area keahlian yang harus dimiliki oleh setiap public relations, yang berorientasi kepada masa depan dan mencoba mengantisipasi kejadian yang dapat mengganggu hubungan-hubungan penting. Public Relations memiliki peran penting dalam merencanakan program persiapan krisis, manajemen krisis itu sendiri pada waktu terjadi krisis dan strategi setelah krisis selesai ditanggulangi. 
Webster mendefinisikan krisis sebagai titik balik (turning point) untuk menuju keadaan lebih baik atau lebih buruk (turning point for the better or worse), jadi lebih dari suatu situasi ini mungkin perusahaan atau organisasi dapat menjadi lebih baik atau lebih buruk. Akan tetapi krisis akan menjadikan organisasi menjadi lebih baik atau lebih buruk sangat tergantung pada bagaimana pihak manajemen mempersepsikan dan kemudian merespon situasi tersebut atau sangat tergantung pada pandangan, sikap atau tindakan yang diambil terhadap krisis tersebut. Pihak manajemen Pelindo mungkin belum dapat melihat lingkungan organisasinya juga berpotensial menghasilkan bencana, maka belum ada perencanaan krisis sebagai bahan dari perencanaan strategis dan mengalokasikan sumberdaya yang memadai untuk itu.

Meskipun tidak ada perencanaan manajemen krisis sebelumnya oleh Pelindo, akan tetapi strategi manajemen krisis yang dilakukan Pelindo selaras dengan teori yang ada menurut Firsan Nova (Nova, 2009) dan Rhenald Kasali, yakni dalam upaya pengendalian krisis, perusahaan dapat melakukan dengan cara peramalan krisis (forcasting) dan pencegahan krisis, yang terlihat dari peran manajemen resiko Pelindo dalam menekan kemungkinan kejadian kecelakaan di alur pelayaran. Serta intervensi krisis atau penanganan terhadap krisis dengan strategi adaptive yakni melakukan tindakan yang berupa modifikasi operasional untuk melakukan kelancaran kegiatan pelabuhan, kompromi dalam mencari solusi, dan komunikasi krisis untuk meluruskan citraperusahaanakibatkejadiankrisis.

Krisis ini membawa keterkejutan dan sekaligus mengancam nilai-nilai penting organisasi serta hanya ada waktu yang singkat untuk mengambil keputusan. Situasi dialami oleh Pelindo ketika kejadian kecelakaan terjadi dan tidak dapat diprediksi sebelumnya bahwa proses evakuasi akan mendapatkan kesulitan dan memakan waktu yang lama.
Penilaian masyarakat atau publik dapat berubah karena krisis yang terjadi. Dan tentu saja, ini merupakan opini publik yang tidak menguntungkan bagi Pelindo Pontianak. Untuk menjelaskan krisis ini bisa dilihat melalui lamanya proses evakuasi yang mengakibatkan hambatan kapal untuk pelayaran di alur pelabuhan dan dampak yang ditimbulkan oleh krisis ini cukup besar meluas ke aspek ekonomi masyarakat di satu daerah. Ini merupakan krisis yang mengancam citra dan kepercayaan publik pada Pelindo. Tekanan permasalahan ini juga berdampak pada meningkatnya sorotan terhadap manajemen PT Pelindo Pontianak. Dengan adanya berbagai permasalahan Pelindo, antara lain masalah alur dan pemanduan kapal, akan menambah gairah media massa untuk mengungkap kompetensi manajemen PT Pelindo Pontianak. Keingintahuan media massa tentunya akan mengundang permasalahan baru lagi dan menambah kompleksitas permasalahan di PT Pelindo Pontianak. Hubungan dengan pihak media yang belum pernah intens sebelumnya menjadi faktor membentuk opini dan persepsi negatif di masyarakat terhadap Pelindo. Apalagi kurangnya pengetahuan dari publik mengenai perusahaan Pelindo menambah sulitnya meluruskan informasi bahwa Pelindo sebagai penyedia layanan jasa pelabuhan dan otoritas alur pelayaran ada pada institusi Adpel, sehingga kepengurusan alur bukan sepenuhnya tanggungjawab dari Pelindo. Dengan adanya situasikrisisyangberdampakluas pada masyarakat tentu saja informasi ini tidak akan berpengaruh banyak pada persepsi publik sebelumnya.

Melihat perkembangan krisis di PT. Pelindo II (Persero) Pontianak, nampaknya permasalahan sudah mencapai tahap kronis dengan mempertimbangkan hal-hal berikut: Dampaknya meluas pada kegiatan ekonomi suatu wilayah. Melibatkan banyak pihak untuk menyelesaikan permasalahan. Hal ini berarti, insiden ini telah menjadi perhatian besar media massa, artinya menjadi perhatian masyarakat 
luas. Kerugian besar dialami berbagai pihak. Proses evakuasi berjalan cukup lama karena kendala dan kesulitan yang ditemui dilapangan tidak dapat ditangani segera. Dari kaca mata public relations, pada saat masalah yang dihadapi perusahaan telah menjadi perhatian publik atau masyarakat luas, maka masalah ini sudah berada dalam tahap kronis. Krisis dengan tahap kronis memerlukan penanganan yang sangat intens dan dilakukan secara sistematis.

Apa yang telah didapatkan PT Pelindo saat ini sesuai dengan kerja keras yang dilakukan dengan bantuan berbagai pihak. General Manager selaku pimpinan tertinggi yang melakukan aktivitas public relations dalam mengkomunikasikan informasi dan penanganan pihak manajemen kepada seluruh pihak terkait dinilai cukup berhasil. Hal tersebut juga berpengaruh dalam mensosialisasikan keberadaan serta hasil kerja Pelindo kepada masyarakat.

Strategi yang digunakan praktisi public relations dalam merespon krisis menunjukkan bagaimana sikap yang diambil oleh organisasi pada saat krisis sedang berlangsung, sehingga posisi public relations dalam manajemen krisis bisa diibaratkan sebagai ujung tombak. Agar fungsi strategis ini dapat dijalankan dengan baik, posisi bidang Public Relations harus langsung dibawah pimpinan puncak. Menurut Cutlip \& Center, dalam bukunya Effective Public Relations mengatakan bahwa idealnya bagian Humas dimasukkan dalam staf inti, langsung berada dibawah pimpinan (decision making) atau top managers, agar lebih mampu menjalankan tugasnya. Dengan posisi tersebut praktisi public relations dapat mengetahui secara langsung latar belakang dari suatu keputusan yang diambil oleh pimpinan lembaga, sehingga langsung mendapat bahan informasi untuk disampaikan kepada publik yang bersangkutan. Dengan demikian public relations mempunyai kewenangan yang memungkinkan fungsi tersebut dapat dijalankan secara efektif. Dalam kaitannya dengan penanganan krisis, public relations memiliki tanggung jawab besar, mengingat dampak negatif dan kerugian besar, bahkan citra organisasi atau perusahaan akan terancam dengan adanya krisis.

\section{Simpulan}

Manajemen Pelindo dalam mengatasi krisis dengan menggunakan strategi adaptif dengan langkah-langkah penanganan krisis yang cukup luas yaitu modifikasi operasional, kompromi, dan meluruskan citra dengan selalu menjaga jaringan komunikasi. Karena tidak adanyanya tim manajemen krisis didalam penanganan ini, General Manager Pelindo langsung membuat general plan atau rencana umum di dalam manajemen untuk bereaksi terhadap krisis.

Ketika menghadapi krisis humas Pelindo tidak banyak berperan sebagai bagian dari manajemen krisis, humas Pelindo diinstruksikan melakukan tugas pengumpulan data atau informasi tentang perkembangan evakuasi untuk pimpinan atau manajemen. Sedangkan untuk komunikasi eksternal humas hanya mengkoordinir agar semua bentuk informasi didapatkan langsung dari General Manager selaku spoke person manajemen Pelindo dalam situasi krisis ini. Strategi manajemen krisis yang dijalankan humas Pelindo telah berhasil membentuk one gate keeper untuk menghindari kesimpangsiuran berita dan mis-komunikasi antara perusahaan kepada publik maupun pihak-pihak luar lainnya. General Manager Pelindo selaku pimpinan tertinggi perusahaan telah berhasil menjalankan aktivitas public relations, menangani dan cepat tanggap untuk mempersiapkan rencana umum dalam manajemen serta mencari jalan keluar atau sebagai problem solver bersama pihakpihak eksternal terkait tentunya. Selain itu General Manager berusaha memastikan bahwa perusahaan sudah secara cepat dan akurat memberikan informasi kepada publik, dengan mengumpulkan informasi perkembangan terbaru mengenai situasi di lapangan. General Manager bertugas mengkoordinir semua bentuk komunikasi dengan media, selama situasi krisis 
pimpinan perusahaan Pelindo berperan sebagai juru bicara perusahaan sebagai pertimbangan bahwa kasus ini telah menyita perhatian banyak pihak serta berdampak luas pada masyarakat dan daerah, tentunya General Manager selaku pimpinan perusahaan adalah orang yang paling kredibel dalam memberi tanggapan dan berkomunikasi mewakili organisasi. Setiap perusahaan memerlukan juru bicara sebagai wakil dari perusahaan untuk berkomunikasi dengan publiknya. Ketika perusahaan berada dalam situasi krisis, publik biasanya hanya mau mendengar dari orang yang mempunyai kekuatan dan berkepentingan untuk menjelaskan, apa yang sebenarnya terjadi dan bagaimana perusahaan akan mengatasinya. Sudah cukup ideal sebagai tim Pelindo dan Adpel bekerjasama untuk membereskan masalah. Kerjasama, peduli terhadap kejadian, dan komunikasi yang terbuka adalah tiga kunci keberhasilan manjemen krisis.

\section{Daftar Pustaka}

Afdhal, Ahmad Fuad. (2004).Tips \& Trik Public Relations. Grasindo. Jakarta. Kurniasari, A., Lestari, P., \& Isbandi. (2008). Strategi Marketing Public Relations Pt. Telkom Kancatel Pati Dalam Program "Flexi Door To Door" Dan "Speedy Go To School" Untuk Membangun Brand Awareness Dan Brand Knowledge Di Wilayah Pati. Junal Ilmu Komunikasi Vol. 6. Luhukay, M. S. (2008). Penerapan Manajemen Krisis di Indonesia: Memotret Krisis dalam Kacamata Public Relations. Jurnal Ilmiah SCRIPTURA, Vol. 2 No. 1, 18-28. Mulyadi, M. (2011). Penelitian Kuantitatif dan Kualitatif Sera Pemikiran Dasar Menggabungkannya. Jurnal Studi Komunikasi dan Media Vol. 15, 127-138. Nova, Firsan. (2009). Crisis Public Relations. Gramedia Widiasarana Indonesia. Jakarta. 